\title{
CROSS-BORDER ACQUISITIONS \\ IN CENTRAL AND EASTERN EUROPE \\ WITH FOCUS ON RUSSIA VERSUS \\ GERMANY DEALS: AN EMPIRICAL ANALYSIS
}

\author{
Tim Langenstein, Anna Vojtková, Martin Užík, Andreas Ruepp
}

\section{Introduction}

Cross-border mergers and acquisitions (M\&As) have gained popularity over the last two decades (Erel, Liao, \& Weisbach, 2012). They have become a dominant form of foreign direct investment in world economy (Zhu, 2011). Research on this type of expansion strategy, however, has not kept pace with this trend and it is highly fragmented, leaving gaps that need to be addressed (Collins et al., 2009). The area of cross-border acquisitions in Central and Eastern Europe, which is also of interest in this paper, represents such a gap.

The progress of globalization positively influenced the worldwide acquisition and merging activities of companies. However, there are some facts and trends in the world economy that highlight the importance and specificity of M\&As in Central and Eastern Europe. These facts and trends hang especially with the development after 1993, when a vast number of mergers were followed by an unprecedented increase of worldwide transactions. To some extent, this development was caused by changes of the political landscape in Europe and the relationships among European countries. Because of fall of the "iron curtain", the proceeds of European integration, mainly the European single market, have created new possibilities. As a result, companies have been forced to develop and implement new expansion strategies. Motivated by the promise of value creation for their shareholders, multinational corporations have begun to use cross-border M\&As as an important tool to acquire key resources and gain market entry to Central and Eastern European markets (Zhu, 2011; Gavurová, Vagašová, \& Kováč, 2016).

As understanding the problem and opportunities of cross-border acquisitions in
Central and Eastern Europe is the essential element in understanding the nature of the upto-date global expansion strategy of a company from an emerging market connected to the $E U$, the main aim of this paper is to analyze announced and completed cross-border acquisitions between a public listed acquirer and target companies from Central and Eastern Europe concentrating on the associated reactions of the capital markets. The empirical analysis focuses on companies from Russia and Germany as dominant acquirers in this context (Statista, 2018).

Taking into account the above, following hypotheses are tested in this paper:

Hypothesis 1: Capital market believes that the effects of the investments realized in the form of cross-border acquisitions in Central and Eastern European markets are positive.

Hypothesis 2: Russian market is better in the area of cross-border acquisitions than remaining Central and Eastern European markets.

Analysis results indicate that Central and Eastern Europe are very attractive from market's perspective due to the expected growth rates and the framework conditions as well as from the perspective of Western European investors, and that the Russian market is better in the area of cross-border acquisitions than remaining Central and Eastern European markets. Analysis results also show that effects of investments realized in form of cross-border acquisitions in Central and Eastern Europe are positive, and changes in stock prices are statistically significant. These findings provide some support to the synergistic and investment opportunity arguments of M\&As in emerging markets asserted by Chari, Ouimet, and Tesar (2004). 
The remainder of this paper proceeds as follows. Section 1 provides the review of relevant literature. Section 2 explains the main motives for cross-border M\&As in Central and Eastern Europe. Section 3 describes the sample and the research methodology. Section 4 presents the results, and Section 5 summarizes and concludes it all.

\section{Literature Review}

The progress of globalization (Hitt et al., 1998; Hitt, Keats, \& DeMarie, 1998), related increased economic integration (Bjorvatn, 2004) and liberalization of international trade (Hijzen, Göro, \& Manchin, 2008), together with accelerated development of technology (Conklin, 2005) positively influenced the worldwide acquisition and merging activities of companies. As a consequence of business environment transformation, firms required new resources and alternatives for strategic expansion and strengthening their own competitiveness, and M\&As seemed to be a relatively flexible (Rani, Yaday, \& Jain, 2016), fast (Vasconcellos \& Kish, 1998) and financially attractive (Conklin, 2005) response to this need (see also Moeller, Schlingemann, \& Stulz, 2004; Nadolska \& Barkema, 2007). Not the fact that M\&As are one of the largest and riskiest capital budgeting projects that companies undertake has impeded the global growth of interest in M\&As. The proof for this is the rise in total transaction value in M\&As from about $\$ 151$ billion in 1990 to more than $\$ 721$ billion in 2016 (UNCTAD, 2000; 2016), and the rationale for this may be attributed in part to a difference in companies' motives for realizing such a deal (Boubakri, Chan, \& Kooli, 2012).

Deals belonging to M\&As began to appear more pronounced as far back as in the early $20^{\text {th }}$ century in the U.S., where a large number of smaller companies began to join the so-called trusts in order to gain a competitive advantage in a rapidly consolidating global market (Spodniak \& Cesnak, 2010). Subsequently, since 1993 (Shimizu et al., 2004), a vast number of M\&As was followed by an unprecedented increase of worldwide transactions (Moschieri \& Campa, 2014). As a result, M\&As today are no longer the domain of just U.S. companies (Norburn \& Schoeneberg, 1994).

To some extent, the growth of popularity of M\&As outside the U.S. market was caused by changes of political landscape in Europe and the relationships between European countries (Calori \& Lubatkin, 1995). Because of the fall of the "iron curtain", the proceeds of European integration, mainly the European single market, have created new possibilities (Bjorvatn, 2004). Thus, in the 1980s, cross-border M\&As seemed particularly attractive to companies wanting to become a part of single European market. While, however, before remaining national barriers came down, the main motive for these deals was a growing concern that unified Europe could transform into a protectionist Fortress Europe, later there were two particular reasons for M\&As of EU firms. Firstly, there was a need to complete the restructuring that had begun in the 1980s which could not be done by companies from the EU member countries alone, and, secondly, there were some regulatory changes that enabled hostile takeovers to occur more easily (Angwin \& Savill, 1997; Vasconcellos \& Kish, 1998). Acquisition and merging activities in the EU subsided just in the late 1980s, when, as stated by Rugman and Verbeke (1991), the steps that were being taken to bring Europe together really created a natural barrier to entry for outsiders.

Bjorvatn (2004) and Moschieri, Ragozzino, and Campa (2014) also consider the process of regional integration experienced by the EU as a significant factor affecting the growth strategies of companies worldwide. They argue that development of the EU has created a more fluid environment for firms seeking international growth via M\&As, despite the differences that continue to exist across the EU members. Ongoing business environment transformation in the EU, namely puts pressure on firms to restructure both internally and externally, and accompanied deregulation raises many incentives to undertake cross-border M\&As in this region of Europe (see also Weston, Chung, \& Hoang, 1998; Rossi \& Volpin, 2004; Rao \& Reddy, 2015).

Thus, in the course of time, motivated by the promise of value creation for their shareholders, multinational corporations have begun to use cross-border M\&As as an important tool to acquire key resources and gain market entry to Central and Eastern European markets (Zhu, 2011). The situation has mainly arisen as the countries of Central and Eastern Europe began to loosen high barriers and restrictions on foreign participation in the early 1990s (Conklin, 2005). The industrial development of many 
Central and Eastern European economies, their rapid economic growth (DePamphilis, 2015; Gavurová, Vagašová, \& Kováč, 2016), and their deepening connection to the EU (Grigorieva \& Petrunina, 2015) have also been a powerful driver of this development.

The need to focus on M\&As in Central and Eastern Europe is supported also due the fact that one of the main results of globalization is a greater role of emerging markets in the world economy (see also Boubakri, Chan, \& Kooli, 2012; Marković, Rakita, \& Filipović, 2016). Chari, Chen, \& Dominquez (2012) also state that while foreign investment has traditionally flowed from developed to developing countries, in recent years there has been an inverse trend.

One of the shortcomings of the extant M\&A literature is just the relative inattention to crossborder M\&As in and out of emerging economies, resp. in and out of Central and Eastern European markets. In contrast to mergers and acquisitions in developed countries, which have been analyzed by a large number of studies (e.g. Conn \& Connell, 1990; Chen \& Su, 1997; Hitt et al., 1998; Andrade, Mitchell, \& Stafford, 2001; Seth, Song, \& Pettit, 2002; Aw \& Chatterjee, 2004; Campa \& Hernando, 2004; Goergen \& Renneboog, 2004; Chari, Quimet, \& Tesar, 2004a,b; Kiymaz, 2004; Lowinski, Schiereck, \& Thomas, 2004; Shimizu et al., 2004; Otchere \& Ip, 2006; Benou, Gleason, \& Madura, 2007; Collins et al., 2009; Rabbiosi, Elia, \& Bertoni, 2012), only a few studies focus on M\&As in and out of emerging markets (e.g. Chari, Ouimet, \& Tesar, 2004; Pop, 2006; Aulakh, 2007; Nagano \& Yuan, 2007; Bris \& Cabolis, 2008; Graham, Martey, \& Yawson, 2008; Trojanowski, 2008; Pablo, 2009; Gregoric \& Vespro, 2009; Gubbi et al., 2010; Bhagat, Malhotra, \& Zhu, 2011; Peng, 2012, Young et al., 2014; Lebedev et al., 2015; Marković, Rakita, \& Filipović, 2016). Central and Eastern Europe are analyzed e.g. by Uhlenbruck and De Castro (2000), Meyer (2003), Lanine and Vander Vennet (2007), Bednarczyk et al. (2010), Brouthers and Dikova (2010) and Poghosyan and de Haan (2010), and the Russian acquisition and merging activities are the main object of interest e.g. by Roberts, Thompson, and Mikolajczyk (2008), Bhagat, Malhotra, and Zhu (2011), Bertrand and Betschinger (2012) and Rabbiosi, Elia, and Bertoni (2012).

This paper is closely related to Sharma and Raat (2016) who focus on the stock market reaction to cross-border acquisition announcements that involve Eastern European emerging-market targets. Using a dataset consisting of 125 deals in which firms from Germany, France, Netherlands, and the United Kingdom acquire ownership stakes in emerging as well as developed-markets in Europe during the period 1 January 2000 through 31 December 2011 , the authors state that when the target firm is located in either the Czech Republic, Poland, Hungary, or Russia, cumulative abnormal return to the acquiring developed-market company shows statistically significant increase of $1.26 \%$ over a three day event window, following the announcement.

\section{Motives for Cross-Border Acquisitions in Central and Eastern Europe}

The acquisition process is a dynamic one (Georgopoulos, Argyros, \& Boura, 2008). It represents one of the largest and riskiest capital budgeting projects that enterprises undertake (Boubakri, Chan, \& Kooli, 2012; Alexandrou, Gounopoulos, \& Thomas, 2014). Numerous authors therefore examine the incentives of companies for M\&As (e.g. Meyer, 2011).

According to Sharma and Raat (2016), the motivations behind cross-border M\&As appear to vary widely, depending on the individual company, the respective industry, the current economic environment, and on other various influencing factors. DePamphilis (2015) state that the drivers of cross-border M\&As are largely similar to those of domestic M\&As, and Horn and Persson (2001), give a fact as the main advantage of a cross-border acquisition that it provides access to foreign market, while a domestic acquisition reduces the competitive pressure in the domestic market (see also Bjorvatn, 2004). Due to their international nature, however, there are some specific factors which drive this cross-border deals, such as favourable regulatory environment and more stable political background in the host country, exchange rates, low foreign tax rates and better client base in the foreign economy (see Fig. 1). Cultural, geographic, and countrylevel governance differences are also important motives for a cross-border transaction (Soltes \& Gavurova, 2014). The same goes for differences in resources and technologies available in the host country. Moeller, Schlingemann, and Stulz (2004) and Boubakri, Chan, and Kooli (2012) 
consider that the main motive for a crossborder acquisition is the value creation for companies' shareholders that usually comes in the form of risk reduction, synergy effects and the acquisition of undervalued assets.

In other words, M\&As provide unique opportunities for the acquirer to gain new capabilities which an enterprise might otherwise find difficult to develop on its own, to grow rapidly, and to gain access to new markets (Degbey \& Hassett, 2016). Zhu, Jog, and Otchere (2014) also give strategic market entry hypothesis as the major motivation for cross border M\&As. They understand M\&As as a rapid way of entering a new market in a new country, and they note that acquirer enters the market cross border by acquiring an already established firm. In this way, the acquirer can take advantage of distribution channels, an established brand name, a qualified labour force, management experience and local knowledge. Cross-border acquisitions give acquiring firms access to resources that may not be available in their home economy, and thereby, they enhance their capabilities to be competitive (Rani, Yaday, \& Jain, 2016).
Neary (2007) views cross-border M\&As as being motivated by market power considerations, and Guadalupe, Kuzmina, and Thomas (2012) state that the cross-border M\&As are initiated in particular by the matching of complementary assets between domestic and multinational companies. Last but not least, some researchers note that M\&As may reduce operating costs and transaction costs, improve efficiency, and enhance the management of resource dependency. Others argue that M\&As are driven primarily by management selfinterest (Sanders, 2001).

Central and Eastern European markets are primarily interesting as they offer high profit margins due to - inter alia - low wage levels and inexpensive production cost (see Eurostat, 2016). Furthermore, there are partly very good conditions for investment to be found especially in new EU-countries. European enlargement and integration has spread the rule of law and constitutional democracy in this region. This set up has led to political stability and brought economic success. From 2005 to 2014 the gross domestic product at market prices in Central and Eastern Europe grew from 6,910 EUR to 11,909 EUR (Eurostat, 2016).

\section{Fig. 1: Motives for cross-border mergers and acquisitions}

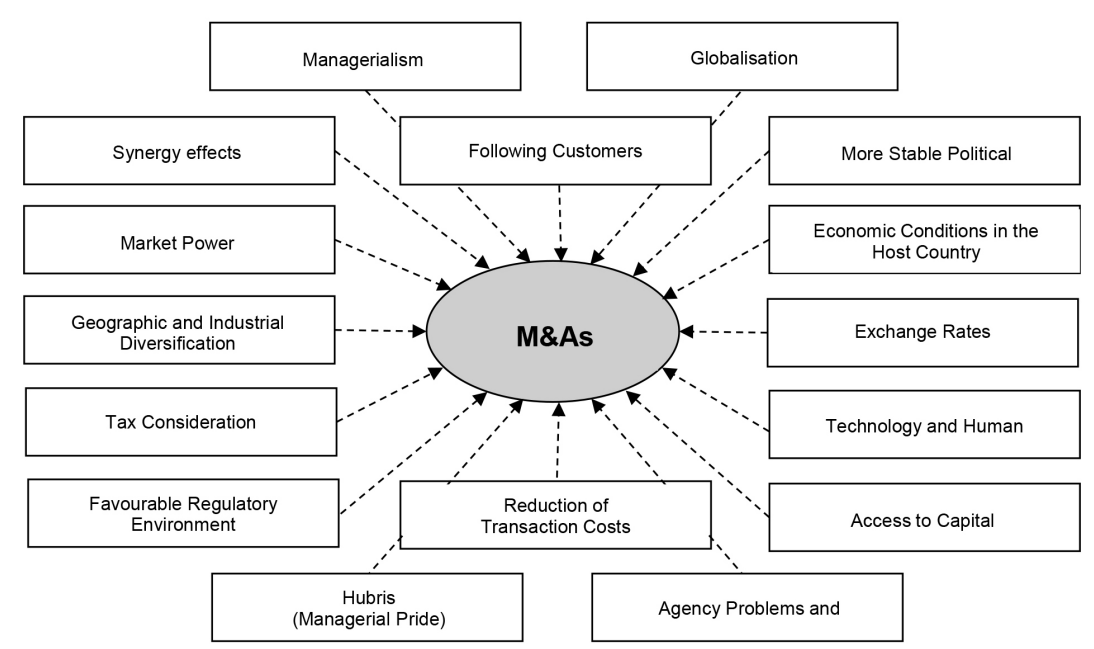

Source: own according to Lebedev et al. (2015), Rani, Yaday, \& Jain (2016) and Sharma \& Raat (2016) 
In particular, two motives are of great importance in the context of cross-border acquisitions between Central and Eastern European and Russian, resp. German companies. One of course are synergy effects, for instance in the form of potential cost saving, purchase of expertise and extensions in the value chain. The other main motive is market driven: gaining market shares and acquiring new products as well as overcoming of market entry barriers. It is all about retaining or winning a competitive advantage.

The deepening of European single market and European Union's enlargement towards Central and Eastern Europe improved the acquisition conditions for companies in that part of Europe. Central and Eastern European markets are primarily interesting as they offer high profit margins due to - inter alia - low wage levels and inexpensive production cost (see Eurostat, 2016). It is no surprise that both strategic and institutional investors find such circumstances worth considering. Furthermore, there are partly very good conditions for investment to be found especially in new EU-countries. European enlargement and integration has spread the rule of law and constitutional democracy in this region. This set up has led to political stability and brought economic success. From 2005 to 2014 the gross domestic product at market prices in Central and Eastern Europe grew from 6,910 EUR to 11,909 EUR (Eurostat, 2016).

\section{Data and Methodology \\ 3.1 Data}

In present empirical analysis, all announced takeovers by a Central or Eastern European company in the period from 1 January 1990 to 30 June 2014 are examined. The time frame reflects fundamental changes in the overall environment as mentioned earlier, and covers recent global financial and economic crisis and European sovereign debt crisis, i.e. the time frame that few have studied. Due to the limited scope of this paper, however, the more detailed analysis of the sample and effects associated with the crisis is not part of the presented empirical analysis.

The initial sample involves 11,085 deals. The final sample relates only to transactions with Russian and German companies. The sample consists of 150 transactions. The data originate from both the mergers and acquisitions database by Bloomberg (Data from 15 March 2005 to 30 June 2014) and the mergers and acquisitions database by Thomson Financials (Data from 1 January 1990 to 15 March 2005). The limitations of the analysis resulting from a structural break in the data are taken into account when interpreting results. The statistical analysis was carried out using the software SPSS.

The outcomes of primary analysis of the cross-border takeovers in Central and Eastern Europe in section 4.1 are followed by the statistical analysis of capital market's reactions in the aftermath of an announced cross-border takeover of a Russian company by a German company and vice versa in section 4.2. The paper focuses on 22 Central and Eastern European target countries (Albania, Bosnia and Herzegovina, Bularia, German Democratic Republic - until 1990, Estonia, Yugoslavia, Croatia, Latvia, Lithuania, Macedonia, Poland, Romania, Russia, Serbia, Slovak Republic, Slovenia, Czech Republic, Czechoslovakia - until 1993, Hungary, Ukraine, Belarus) affected by cross-border acquisitions by either Russian or German companies.

\subsection{Methodology}

The research methodology is based on determination of the expected reference rate of return and on calculation of the excess returns which were made in the following way.

\section{1) Determination of expected reference rate of return}

In order to determine abnormal excess returns, the reference rate of return is calculated according to a market model. The market model is based on Markowitz (1959) and assumes a linear coherence between the return from commercial papers and market portfolio.

$$
R_{i, t}=\alpha_{i}+\beta_{i} R_{m, t}+\varepsilon_{i, t}
$$

where $R_{i, t}$ is the return on security $i$ at day $t ; \alpha_{i}, \beta_{i}$ are parameters; $\varepsilon_{i, t}$ is noise; and $R_{m, t}$ is the return on the market at day $t$.

Alpha and beta parameters are determined with the OLS method in the context of this study. The estimation period ends one day prior to beginning of the event period in order to avoid any overlapping. Central within the observation is the day of the announcement. The event period comprises 20 days around the day of the announcement. As the estimation period 
for the determination of the market model's parameters, a period of 748 to 20 days prior to the event period is used (for general remarks on the market model and the determination of the length of estimation period see Wulff (2001, p. 116). This period covers 728 trading days. The Stoxx-EURO 600 Index is used to determine the return of the market portfolio.

\section{2) Calculation of the excess returns}

The difference between effectively realized and theoretically anticipated return of a share expresses the excess return. In the informationefficient market and under the condition of the concurrent validity of the model consulted in order to determine the expected return, there do not exist systematic deviations of the two return figures.

$$
E\left(A R_{i, t}\right)=0
$$

whereby the excess return is calculated as follows:

$$
A R_{i, t}=R_{i, t}-E\left(R_{i, t}\right)
$$

where $A R_{i, t}$ is the abnormal return of the share $i$ at day $t, R_{i, t}$ is observed return of the share $i$ at the stock exchange at day $t$, and $E\left(R_{i, t}\right)$ is expected return of the share $i$ at day $t$.

In literature, the additive as well as the multiplicative conjunction of the excess returns and the determination of buy-and-hold excess returns are used to determine cumulated excess returns. Empirical studies mainly use the additive determination procedure (for the calculation of cumulative excess returns see Mitchell and Stafford (2000)).

The additive approach of determination of cumulated excess returns traces back to the work of Fama et al. (1969) and is determined as follows:

$$
C A R_{i, \tau, L}=\sum_{t=\tau}^{t=\tau+L} A R_{i, t}
$$

The multiplicative conjunction of the excess returns was produced by Ball and Brown (1968). The result of a cumulated multiplicative compression of excess returns is captured in an abnormal-performance-index (API). In the present study it is resorted to the additive capture of the cumulated excess rates (see Wulff (2001, p. 134)).

\section{Results and Discussion of Findings}

4.1 Cross-Border Acquisitions in Central and Eastern Europe

The contemplation of the particular transferees by their company's domicile shows that most of the announcements of an Central or Eastern European cross-border transaction were stated by a company that has its registered office in Central or Eastern Europe (these enterprises are summarized in "Central and Eastern Europe" category). However, this surprising fact can be explained by the definitional distinction of a cross-border acquisition by Thomson Financial. According to Thomson Financial, a M\&A transaction by a transferee that has its registered office in the Central or Eastern European market, the acquisition target, is defined as a cross-border transaction in case the transferee's parent company has its head office outside of that market.

Tab. 1 shows M\&A distribution according to geographical area of both the acquiring and the target firm. $44.5 \%$ of all operations were announced by firms from the United Kingdom.

If we leave Central and Eastern Europe cross-border acquisitions out of consideration then US companies are the most common transferees with 1,208 announced cross-border acquisitions, followed by German companies with 998 announcements in Central and Eastern Europe.

Economic development of the respective Central and Eastern European countries, as well as the geographical proximity to Western European countries seem like the essential criteria in the decision making process. Companies from Poland, Czech Republic, Slovakia, Hungary and Russia are included in almost $63 \%$ of the announcements, which are all - except Russia - close to Western Europe. Furthermore, German transferees prefer an acquisition target from one of these countries in $76 \%$ of all cases. Moreover, as can be seen from the figure, most of the announced transactions with 2,289 acquisition targets came from Russia, followed by Poland with 1,881 and Czech Republic with 1,374 acquisition intentions.

Regarding the companies that are summarized in the overall category "Central and Eastern Europe“, it becomes apparent that most of the announcements were made between companies in the same region. 


\section{Tab. 1: Geographical assignment of the acquirer and the acquisition targets}

\begin{tabular}{|c|c|c|c|c|c|c|c|c|c|c|c|c|c|c|c|c|c|c|c|c|c|c|c|c|}
\hline \multirow[b]{2}{*}{$\begin{array}{l}\text { Acquirer } \\
\text { Nation }\end{array}$} & \multicolumn{23}{|c|}{ Target Nation } & \multirow[b]{2}{*}{ 壹 } \\
\hline & 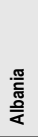 & 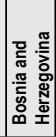 & 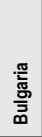 & 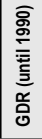 & 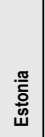 & 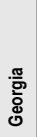 & $\begin{array}{l}\frac{\pi}{2} \\
\frac{\pi}{0} \\
\frac{0}{0} \\
\frac{9}{2}\end{array}$ & 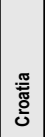 & $\sum_{J}^{\mathbb{J}}$ & 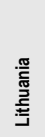 & $\begin{array}{l}\frac{\pi}{5} \\
\frac{0}{0} \\
\frac{0}{0} \\
\frac{\pi}{2}\end{array}$ & $\frac{\frac{\pi}{2}}{\frac{\pi}{\pi}}$ & 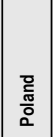 & 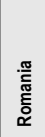 & 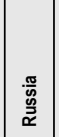 & 高 & 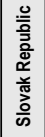 & $\begin{array}{l}\frac{\pi}{\frac{\pi}{\sigma}} \\
\frac{0}{0}\end{array}$ & $\begin{array}{l}\frac{0}{0} \\
\bar{z} \\
\frac{0}{0} \\
\frac{\alpha}{0} \\
\frac{c}{0} \\
\mathbb{J}\end{array}$ & 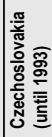 & 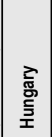 & 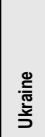 & & \\
\hline Argentina & & & & & & & & & & & & & 1 & 1 & & & & & & & & & & 2 \\
\hline Bahamas & & & & & & & & & & & & & & 1 & 1 & & & & 11 & & 1 & & & 14 \\
\hline Belgium & & 2 & 15 & & 1 & & 2 & 4 & 2 & & & & 40 & 9 & 15 & 4 & 9 & 6 & 39 & 16 & 20 & 3 & 1 & 188 \\
\hline Bermudas & & & 2 & & & 6 & & 1 & & 1 & & & 2 & 1 & 2 & & & & 6 & 1 & 2 & 2 & & 26 \\
\hline Brazil & & & & & 1 & 1 & & 1 & & & & & 2 & & & & 1 & & 1 & & & & & 7 \\
\hline Cayman Island & & & & & & & & 3 & & & & & & & 1 & & & 1 & 1 & & & & & 6 \\
\hline Chile & & & & & 2 & & & 2 & & & & & & & & & & & & & & & & 4 \\
\hline Denmark & & & 6 & & 12 & & & 4 & 10 & 31 & & 1 & 58 & 4 & 12 & 2 & 6 & 5 & 21 & 8 & 15 & 2 & & 197 \\
\hline Germany & 3 & 2 & 29 & 25 & 14 & 1 & 5 & 28 & 13 & 16 & 5 & 4 & 249 & 30 & 67 & 5 & 35 & 21 & 197 & 46 & 188 & 15 & & 998 \\
\hline Finland & & & & & 120 & 1 & & 1 & 39 & 37 & & & 43 & 3 & 62 & & 8 & 3 & 14 & 7 & 16 & 1 & & 355 \\
\hline France & & & 15 & 2 & 5 & & 3 & 7 & 2 & 1 & 1 & & 159 & 38 & 51 & 3 & 19 & 14 & 85 & 35 & 108 & 8 & 1 & 557 \\
\hline Greece & 4 & & 33 & & 1 & 1 & 7 & 2 & & 1 & 22 & & 7 & 39 & 8 & 9 & & & 4 & 1 & 13 & & & 152 \\
\hline Ireland & & & 6 & & 1 & & & & 2 & 3 & & & 21 & 1 & 13 & & 4 & & 4 & & 8 & 4 & & 67 \\
\hline Iceland & & & & & 2 & & 1 & & 3 & 3 & & & 1 & 1 & & 1 & & & & & 3 & & & 15 \\
\hline Italy & 1 & 2 & 13 & & 6 & & 4 & 15 & 5 & 3 & 1 & & 35 & 31 & 13 & 4 & 14 & 10 & 31 & 9 & 38 & 3 & 1 & 239 \\
\hline Japan & & & 3 & & & & & 1 & 1 & 1 & & & 12 & 5 & 8 & & 1 & & 7 & 1 & 10 & 8 & & 58 \\
\hline Canada & & & 3 & & 2 & 3 & & 1 & & 1 & & & 24 & 9 & 56 & 1 & 5 & 6 & 25 & 9 & 18 & 6 & & 169 \\
\hline Liechtenstein & & & 1 & & & & & 1 & & & & 1 & & & 2 & & & & 2 & & 1 & 1 & & 9 \\
\hline Luxembourg & & & 4 & & 2 & & & 1 & & 3 & & & 23 & 5 & 12 & & & & 6 & 2 & 6 & 2 & 1 & 67 \\
\hline Malta & & & & & & & & & & & & & 1 & & 3 & & & & & & 1 & & & 5 \\
\hline Netherlands & 2 & 1 & 20 & & 8 & 1 & 3 & 8 & 8 & 6 & & 1 & 103 & 26 & 34 & & 17 & 5 & 75 & 26 & 87 & 3 & 1 & 435 \\
\hline Norway & 1 & & 2 & & 26 & & 1 & 1 & 10 & 15 & & & 26 & 9 & 27 & & 6 & 7 & 15 & 4 & 8 & 6 & & 164 \\
\hline Austria & 1 & 7 & 27 & & 6 & 2 & 4 & 29 & 1 & & 2 & 1 & 56 & 31 & 10 & 2 & 50 & 22 & 103 & 24 & 117 & 7 & 5 & 507 \\
\hline Panama & & & & & & & & & & & & & & & & & & & & & 1 & & & 1 \\
\hline Portugal & & & & & & & & & & & & & 17 & 1 & & & & & 2 & & 2 & & & 22 \\
\hline Switzerland & & & 17 & & 4 & 1 & 2 & 4 & 2 & 1 & 2 & 1 & 34 & 16 & 35 & 3 & 6 & 16 & 38 & 22 & 23 & 19 & & 246 \\
\hline Spain & & & 4 & & 1 & & 1 & & & 2 & & 3 & 32 & 4 & 11 & & & & 7 & 2 & 8 & 2 & & 77 \\
\hline Sweden & & 3 & 5 & & 67 & & 1 & 7 & 32 & 33 & & & 82 & 8 & 56 & 1 & 5 & 7 & 33 & 8 & 16 & 10 & 1 & 375 \\
\hline Turkey & 4 & & 11 & & & 1 & & 1 & 1 & & 1 & & 3 & 13 & 3 & & & & & & 2 & 2 & & 42 \\
\hline UK & 5 & 4 & 36 & 2 & 11 & 10 & 3 & 21 & 15 & 12 & 4 & 4 & 140 & 42 & 192 & 4 & 21 & 30 & 135 & 31 & 85 & 44 & 6 & 857 \\
\hline USA & & 1 & 32 & 1 & 25 & 10 & 3 & 12 & 13 & 16 & 2 & 4 & 241 & 83 & 218 & 6 & 28 & 66 & 176 & 70 & 161 & 33 & 7 & 1,208 \\
\hline Venezuela & & & & & & & & & & & & & & & & & & 1 & & 1 & & 1 & & 3 \\
\hline Cyprus & & & 15 & & & & & & 1 & 1 & & & 7 & 19 & 39 & 1 & 1 & & 6 & 3 & 2 & 12 & & 107 \\
\hline $\begin{array}{l}{ }_{\text {"Central and }} \\
\text { Eastern Europe" }\end{array}$ & 1 & 25 & 94 & & 97 & 17 & 20 & 78 & 78 & 88 & 18 & 15 & 462 & 103 & 1,338 & 29 & 81 & 512 & 330 & 108 & 242 & 146 & 24 & 3,906 \\
\hline Sum & 22 & 47 & 393 & 30 & 414 & 55 & 60 & 233 & 238 & 275 & 58 & 35 & 1881 & 533 & 2,289 & 75 & 317 & 732 & 1,374 & 434 & 1,202 & 340 & 48 & \\
\hline
\end{tabular}




\begin{tabular}{|c|c|c|c|c|c|c|c|c|c|c|c|c|c|c|c|c|c|c|c|c|c|c|c|c|}
\hline \multirow[b]{3}{*}{$\begin{array}{l}\text { Acquirer } \\
\text { Nation }\end{array}$} & \multicolumn{24}{|c|}{$\begin{array}{l}\text { Geographical assignment of the transferees and the acquisition targets within } \\
\text { "Central and Eastern Europe" group }\end{array}$} \\
\hline & \multicolumn{23}{|c|}{ Target Nation } & \multirow[b]{2}{*}{ Sum } \\
\hline & 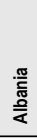 & 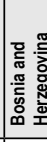 & 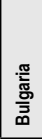 & 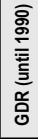 & 咞 & 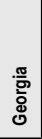 & 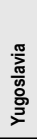 & 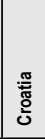 & $\underset{\Xi}{\stackrel{\varpi}{\Xi}}$ & 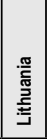 & 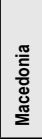 & $\begin{array}{l}\frac{\pi}{2} \\
\frac{\mathrm{n}}{\mathrm{c}} \\
\frac{\mathrm{o}}{2}\end{array}$ & 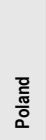 & 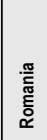 & 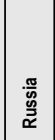 & 竞 & 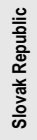 & $\begin{array}{l}\frac{.0}{\bar{E}} \\
\frac{0}{\omega} \\
\frac{0}{\omega}\end{array}$ & 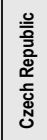 & 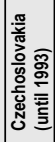 & 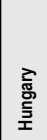 & 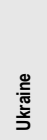 & 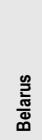 & \\
\hline Albania & 1 & & & & & & & & & & & & & & & & & & & & & & & 1 \\
\hline $\begin{array}{l}\text { Bosnia- } \\
\text { Herzegovina }\end{array}$ & & 3 & & & & & & 1 & & & & & & & & & & & & & & & & 4 \\
\hline Bulgaria & & & 49 & & & & 2 & & & & 3 & & & 1 & 4 & 1 & & & 2 & 1 & & 2 & 1 & 66 \\
\hline $\mathrm{GDR}^{*}$ (until 1990) & & & & & & & & & & & & & & & & & & & & & & & & 0 \\
\hline Estonia & & & & & 65 & & & & 30 & 25 & & & & & 13 & & & & 1 & & 1 & 3 & & 138 \\
\hline Georgia & & & & & & 6 & & & & & & & & & 3 & & & & & & & & & 9 \\
\hline Yugoslavia & & & & & & & 1 & & & & 1 & & & 1 & & & & & & & 1 & & & 4 \\
\hline Croatia & & 7 & & & & & 5 & 33 & & & 1 & & 3 & & 1 & 1 & 1 & 3 & 4 & & 3 & & & 62 \\
\hline Latvia & & & & & 15 & & & & 23 & 10 & & & & & 4 & & & & & & & & 1 & 53 \\
\hline Lithuania & & 1 & & & 4 & & & & 10 & 19 & & & & & 3 & & 2 & & & & 1 & 4 & 2 & 46 \\
\hline Macedonia & & & & & & & 2 & & & & 2 & & & & & & & & & & & & & 4 \\
\hline Moldavia & & & & & & & & & & & & & & 1 & & & & & & & & & & 1 \\
\hline Poland & & & 1 & & 4 & & & & 2 & 12 & & & 417 & 7 & 10 & & 2 & & 10 & 2 & 10 & 10 & 2 & 489 \\
\hline Romania & & & 1 & & & & & & & & & 1 & & 56 & 1 & 1 & & & & & 1 & & & 61 \\
\hline Russia & & 1 & 18 & & 9 & 6 & 1 & 7 & 11 & 19 & 3 & 13 & 7 & 11 & 1,260 & 4 & 4 & & 16 & 8 & 12 & 72 & 17 & 1,499 \\
\hline Serbia & & 2 & & & & & 1 & & & & & & & & & 10 & & 1 & & & & & & 14 \\
\hline Slovak Republic & & 1 & 1 & & & & & 1 & & & & & 1 & & 2 & & 26 & 6 & 27 & 1 & 3 & 4 & & 73 \\
\hline Slovenia & & 9 & & & & & 8 & 22 & & & 7 & & 3 & 1 & 2 & 10 & 7 & 494 & 2 & & & 2 & & 567 \\
\hline Czech Republic & & & 12 & & & 3 & & 1 & & 2 & & & 14 & 3 & 7 & & 25 & 1 & 228 & 89 & & 5 & 1 & 391 \\
\hline $\begin{array}{l}\text { Czechoslovakia } \\
\text { (until 1993) }\end{array}$ & & & & & & & & & & & & & 1 & & 1 & & 6 & & 24 & 2 & & & & 34 \\
\hline Hungary & & 1 & 11 & & & & & 13 & & 1 & 1 & 1 & 13 & 22 & 8 & 2 & 8 & 1 & 16 & 5 & 207 & 6 & & 316 \\
\hline Ukraine & & & 1 & & & 2 & & & 2 & & & & 3 & & 19 & & & 6 & & & 3 & 38 & & 74 \\
\hline Belarus & & & & & & & & & & & & & & & & & & & & & & & & 0 \\
\hline Sum & 1 & 25 & 94 & 0 & 97 & 17 & 20 & 78 & 78 & 88 & 18 & 15 & 462 & 103 & 1,338 & 29 & 81 & 512 & 330 & 108 & 242 & 146 & 24 & \\
\hline
\end{tabular}

Note: * German Democratic Republic

In approximately 1,260 cases, the transferees from Russia chose an acquisition target from Russia (see Tab. 2). In total, most of the crossborder acquisitions had its target in Russia $(1,338)$. Russia also features the companies with majority of acquisition ambitions.

\subsection{Russia versus Germany Deals}

The analysis of the capital market's reactions to the announcement of a cross-border acquisition in Central and Eastern Europe is focused only on Russian and German public listed companies.
In 206 cases, German companies listed on the stock exchange announced cross-border acquisitions of a Russian target or Russian companies listed on the stock exchange announced cross-border acquisitions of a German target. This sample marks the basis of the present study. Out of the transactions, only 56 cases do not deliver sufficient data for empirical analysis. The examination of capital market's reactions is made in a timeframe of 20 days around the day of announcement. The examination focus is on the excess return that is determined by the 


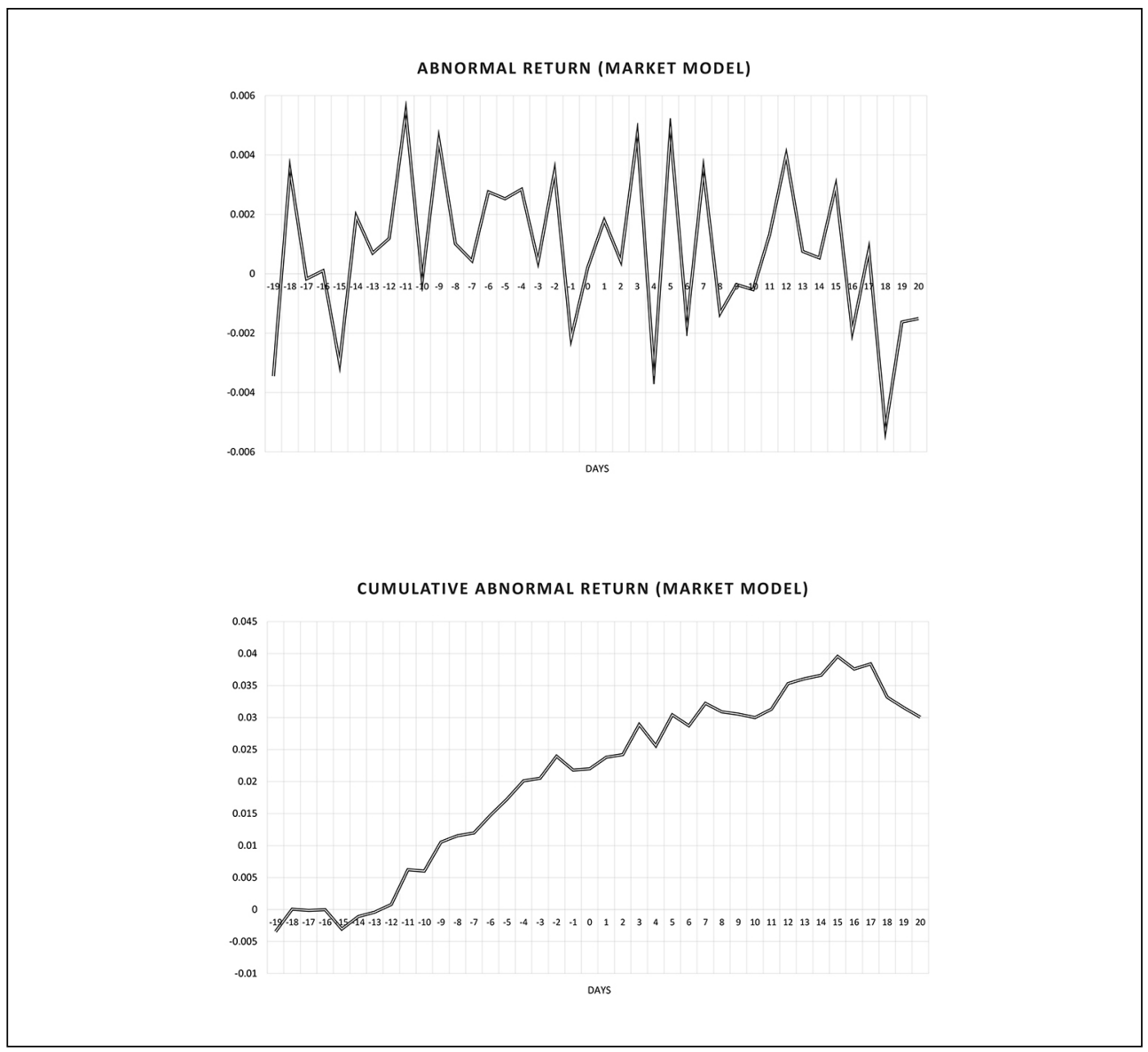

difference between the anticipated and the realized return.

The analysis of abnormal excess returns (see Fig. 2, up) shows no significant deflection of returns at any day in the event period. Therefore, the analysis of cumulated abnormal excess returns must be discussed.

The observation of cumulated excess returns (see Fig. 2, down) shows a positive signal on capital markets with respect to announcements of cross-border takeovers. In the examination period of 20 days around the moment of announcement, the overall return of $3 \%$ could have been realized. However, the value is statistically not significant. On a safety level of $90 \%$, the return of $1.57 \%$ could have been noted in a timeframe of five days around the day of announcement.

The analysis of capital market's reaction (see Tab. 3) shows that the capital market values the cross-border investment between Russian and German companies positively. However, it should be noted that findings gained are exclusively based on the capital market's expectations and the conducted studies cover a short time period. In this sense, we cannot deduce general statements about the actual long-term success of company takeovers in German or Russian market. The results, however, indicate that capital market 
Tab. 3: Statistics (Hypothesis 1)

\begin{tabular}{|c|c|c|c|c|c|c|}
\hline & $\mathbf{N}$ & Mean & $\begin{array}{l}\text { Standard } \\
\text { Deviation }\end{array}$ & $\begin{array}{l}\text { Standard } \\
\text { Error of } \\
\text { the Mean }\end{array}$ & & \\
\hline$+/-20$ days & 57 & 0.032 & 0.190 & 0.025 & & \\
\hline$+/-10$ days & 57 & 0.023 & 0.120 & 0.016 & & \\
\hline$+/-5$ days & 57 & 0.018 & 0.070 & 0.009 & & \\
\hline$+/-2$ days & 57 & 0.003 & 0.064 & 0.009 & & \\
\hline \multirow[t]{3}{*}{ Announced Day } & 57 & 0.001 & 0.024 & 0.003 & & \\
\hline & \multicolumn{6}{|c|}{ Test Value $=0$} \\
\hline & $\mathbf{T}$ & df & $\begin{array}{c}\text { Sig. } \\
\text { (2-side) }\end{array}$ & $\begin{array}{l}\text { Average } \\
\text { Difference }\end{array}$ & \multicolumn{2}{|c|}{$\begin{array}{l}95 \% \text { Confidence } \\
\text { Interval }\end{array}$} \\
\hline +/- 20 days & 1.251 & 56 & 0.216 & 0.031 & -0.019 & 0.082 \\
\hline +/- 10 days & 1.431 & 56 & 0.158 & 0.023 & -0.009 & 0.055 \\
\hline$+/-5$ days & 1.904 & 56 & 0.062 & 0.018 & -0.001 & 0.036 \\
\hline$+/-2$ days & 0.317 & 56 & 0.752 & 0.003 & -0.014 & 0.020 \\
\hline Announced Day & 0.356 & 56 & 0.723 & 0.001 & -0.005 & 0.008 \\
\hline
\end{tabular}

believes the effects of investments realised in form of cross-border acquisitions in Central and Eastern European markets are positive.

Also, the comparison of abnormal and cumulative abnormal return in cross-border acquisitions between Russian and German companies (Fig. 3, Part 1) with abnormal and cumulative abnormal return in cross-border acquisitions in and out of Central and Eastern Europe (including Russia) (Fig. 3, Part 2) highlights the importance of Russian market in the area of M\&As in and out of the Central and Eastern Europe. 56 cross-border acquisitions between Russian and German companies during the period 1990 through 2014 resulted in the abnormal return on announced day at $+0.02 \%$ and in the cumulative abnormal return at $+3 \%$, and 1,731 cross-border acquisitions in and out of Central and Eastern Europe during the period 1990 through 2005 resulted in the abnormal return on announced day at $+0.4 \%$ and in the cumulative abnormal return at $+0.11 \%$.

Finally, the results of analysis show that the abnormal return in a cross-border acquisition between Russian and German firms is at ca. $1 \%$, while cross-border acquisitions in and out of Central and Eastern European markets result in a very low abnormal return near $0 \%$, or in the negative abnormal return (see Fig. 4).
The difference between abnormal returns in cross-border Russia versus Germany deal and cross-border Central and Eastern European deal is, according to a two-sided mean test (see Tab. 4), statistically significant. It means that Russian market is better in the area of crossborder acquisitions than remaining Central and Eastern European markets. It is thus worthier investing in Russia than in remaining Central and Eastern Europe (including Russia).

\section{Conclusions}

Increasing globalization of trade and capital mobility has encouraged many companies to look outside their home country borders to find factors of production that could provide competitive advantages (Vasconcellos \& Kish, 1998). The conducted study focuses on capital markets stance to the investments in Central and Eastern European countries. Specifically, it deals with the market of Russia from the point of view of merging and acquisition activities. Analysis of results shows that cross-border acquisitions in Central and Eastern Europe increased continuously since the beginning of 1990 . The climax was reached in the year of 2000. Russia, Poland, the Czech Republic and Hungary were the focus of takeover intentions. Geographical proximity to an Central or Eastern European 


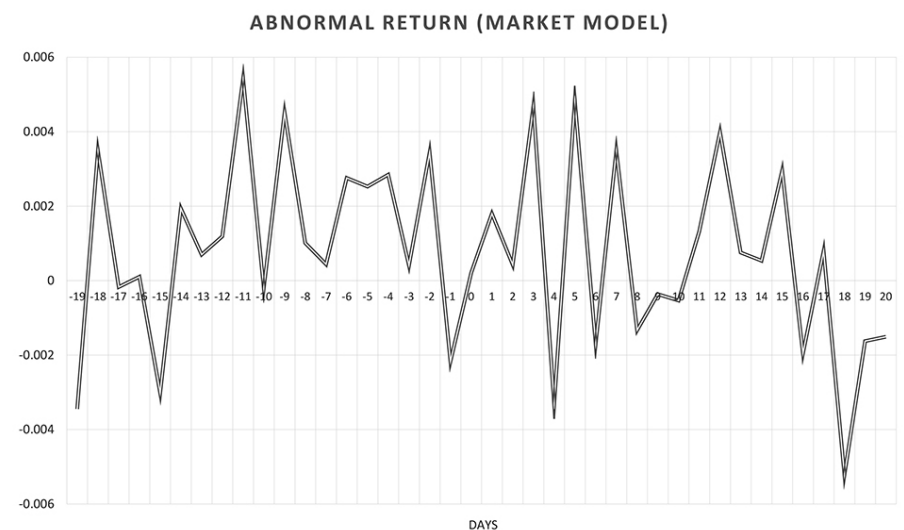

CUMULATIVE ABNORMAL RETURN (MARKET MODEL)

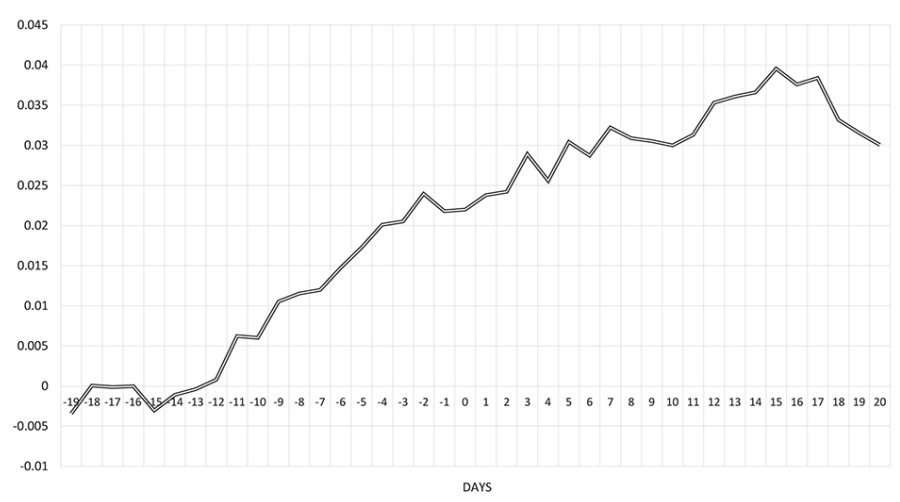

Source: own

Note: *Abnormal and cumulative abnormal return in cross-border acquisitions between Russian and German companies (Part 1) and abnormal and cumulative abnormal return in cross-border acquisitions in and out of Central and Eastern Europe (including Russia) (Part 2).

country seems to be an important decision criterion for Western Europe's transferees. The analysis of the capital market reactions in the timeframe of 20 days around the announcement turns out to be positive. According to capital market's opinion, an investment in form of a cross-border acquisition between Russian and German companies (cumulated abnormal return $(\mathrm{CAR})+3 \%)$ is the most profitable.
In summary, it can be emphasized that Central and Eastern Europe as a region is very attractive from the market's perspective due to the expected growth rates and the framework conditions as well as from the perspective of Western European investors, while the Russian market is better in the area of crossborder acquisitions than remaining Central and Eastern European markets. These findings 
Finance

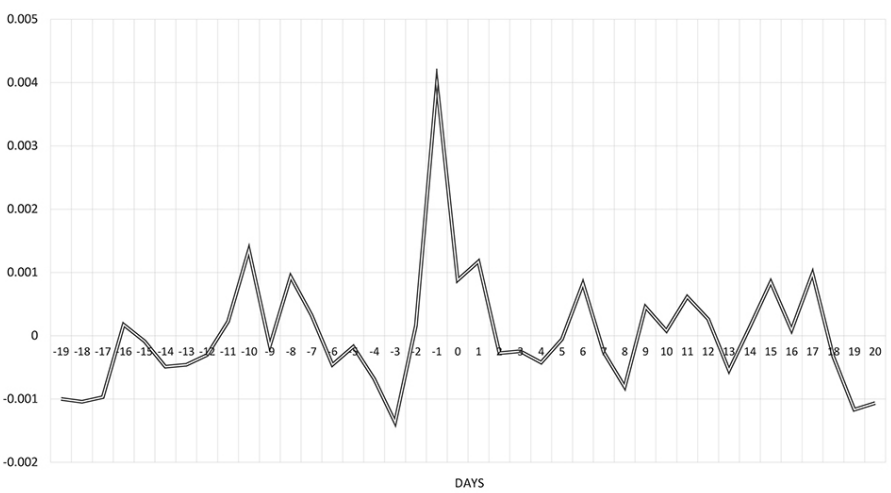

CUMULATIVE ABNORMAL RETURN (MARKET MODEL)

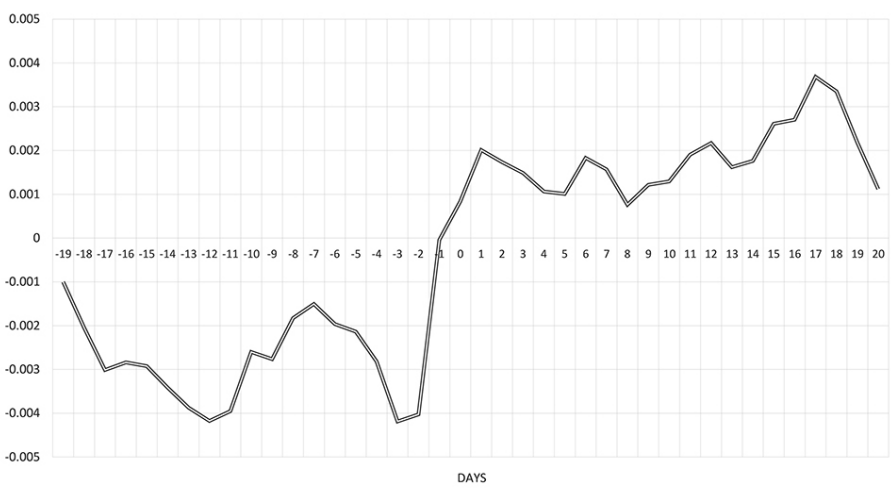

Source: own

Note: *Abnormal and cumulative abnormal return in cross-border acquisitions between Russian and German companies (Part 1) and abnormal and cumulative abnormal return in cross-border acquisitions in and out of Central and Eastern Europe (including Russia) (Part 2). 


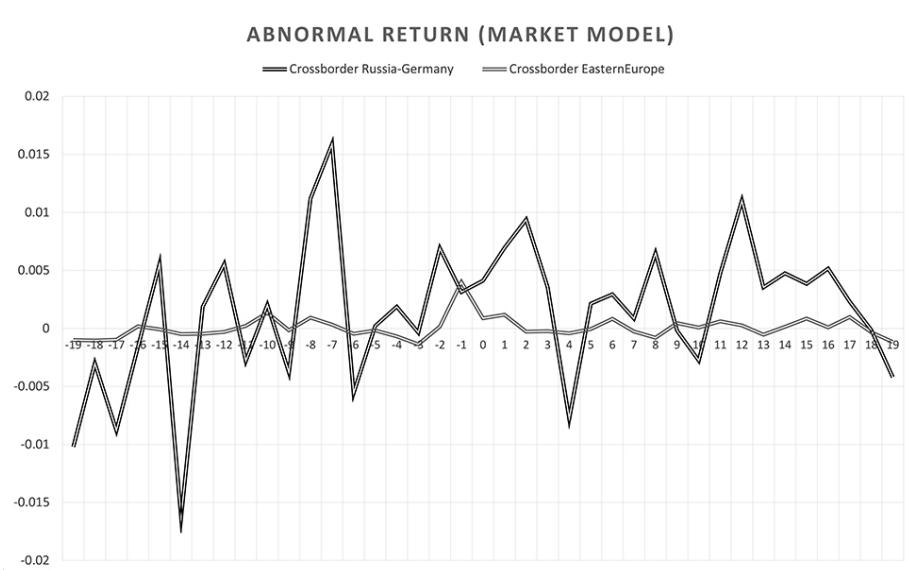

ABNORMAL RETURN (MARKET MODEL)

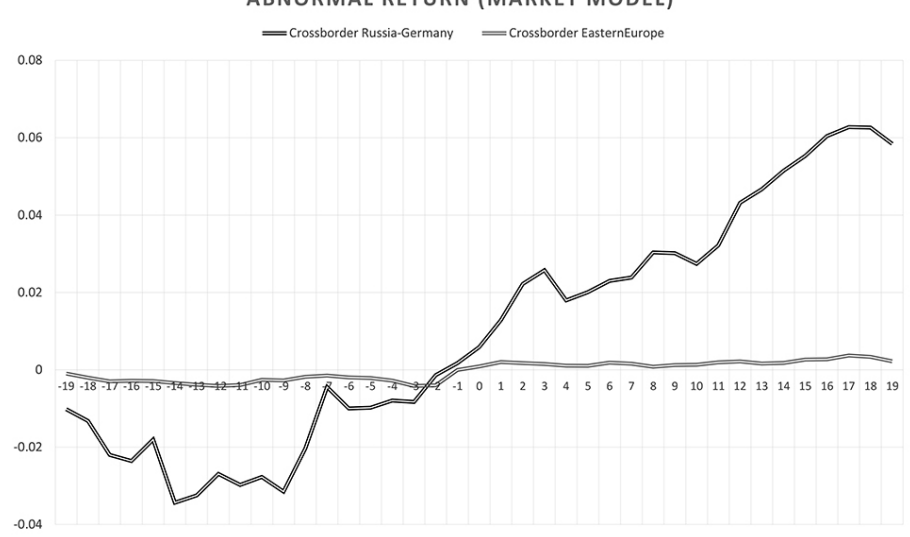

Source: own

\section{Tab. 4: Statistics (Hypothesis 2)}

\begin{tabular}{|c|c|c|c|c|c|c|}
\hline & $\mathbf{N}$ & Mean & $\begin{array}{l}\text { Standard } \\
\text { Deviation }\end{array}$ & $\begin{array}{l}\text { Standard } \\
\text { Error of } \\
\text { the Mean }\end{array}$ & & \\
\hline \multirow[t]{3}{*}{ RDR - MODEL } & 39 & 0.010 & 0.028 & 0.005 & & \\
\hline & \multicolumn{6}{|c|}{ Test Value $=0$} \\
\hline & $\mathbf{T}$ & df & $\begin{array}{c}\text { Sig. } \\
\text { (2-side) }\end{array}$ & $\begin{array}{l}\text { Average } \\
\text { Difference }\end{array}$ & \multicolumn{2}{|c|}{$\begin{array}{c}95 \% \text { Confidence } \\
\text { Interval }\end{array}$} \\
\hline RDR - MODEL & 2.233 & 38 & 0.032 & 0.010 & 0.001 & 0.019 \\
\hline
\end{tabular}


provide some support to synergistic and investment opportunity arguments of M\&As in emerging markets asserted by Chari, Ouimet, and Tesar (2004).

The present study contributes to the literature on M\&As on several grounds. Firstly, the analysis focuses on M\&As in Central and Eastern Europe, the region that few have studied, including all Russia versus Germany M\&A announcements between 1990 and 2014. Secondly, the time frame of the analysis reflects fundamental changes in the overall environment that arose in Europe in the last two decades, and covers the recent serious global financial and economic crisis and European sovereign debt crisis. Thirdly, the study builds on the growth of literature on cross-border $M \& A s$ in and out of emerging markets, and it also draws attention to the hidden potential of acquisition and merging activities in and out of Central and Eastern European economies. The paper thus makes an important contribution to the literature on M\&As by analysing stock market reaction to cross border acquisition announcements involving Central and Eastern European emerging market targets, resp. Russian targets, which is a relatively underresearched area in the literature.

\section{References}

Alexandrou, G., Gounopoulos, D., \& Thomas, H. M. (2014). Mergers and acquisitions in shipping. Transportation Research Part $E, \quad 61, \quad 212-234$. https://doi.org/10.1016/ j.tre.2013.11.007.

Andrade, G., Mitchell, M. L., \& Stafford, E. (2001). New evidence and perspectives on mergers. The Journal of Economic Perspectives, 15(2), 1-70. https://doi.org/10.1257/jep.15.2.103.

Angwin, D., \& Savill, B. (1997). Strategic perspectives on European cross-border acquisitions: A view from top European executives. European Management Journal, 15(4), 423-435. https://doi.org/10.1016/S0263-2373(97)00021-2.

Aulakh, P. S. (2007). Emerging multinationals from developing economies: Motivations, paths and performance. Journal of International Management, 13(3), 235-240. https://doi.org/10.1016/j.intman.2007.05.001.

Aw, M. S. B., \& Chatterjee, R. A. (2004). The performance of UK firms acquiring large cross-border and domestic takeover targets. Applied Financial Economics, 14(5), 337-349. https://doi.org/10.1080/0960310042000211605.

Ball, R., \& Brown, P. (1968). An Empirical Evaluation of Accounting Income Numbers. Journal of Accounting Research, 6(2), 159-178. https://doi.org/10.2307/2490232.

Bednarczyk, T. P., Schiereck, D., \& Walter, H. N. (2010). Cross-border acquisitions and shareholder wealth: Evidence from the energy and industry in Central and Eastern Europe. Journal for East European Management Studies, 15(2), 106-127.

Benou, G., Gleason, K. C., \& Madura, J. (2007). Impact of Visibility and Investment Advisor Credibility on the Valuation Effects of High-Tech Cross-Border Acquisitions. Financial Management, 36(1), 69-89. https://doi. org/10.1111/j.1755-053X.2007.tb00165.x.

Bertrand, O., \& Betschinger, M. A. (2012). Performance of domestic and cross-border acquisitions: Empirical evidence from Russian acquirers. Journal of Comparative Economics, 40(3), 413-437. https://doi.org/10.1016/j.jce.2011.11.003.

Bhagat, S., Malhotra, S., \& Zhu, P. (2011). Emerging country cross-border acquisitions: Characteristics, acquirer returns and cross-sectional determinants. Emerging Markets Review, 12(3), 250-271. https://doi. org/10.1016/j.ememar.2011.04.001.

Bjorvatn, K. (2004). Economic integration and the profitability of cross-border mergers and acquisitions. European Economic Review, 48(6), 1211-1226. https://doi.org/10.1016/ j.euroecorev.2004.03.007.

Boubakri, N., Chan, A., \& Kooli, M. (2012). Are the busiest really the best? Further evidence from frequent acquirers. Journal of Multinational Financial Management, 22(1-2), 1-23. https://doi.org/10.1016/j.mulfin.2011.11.001.

Bris, A., \& Cabolis, C. (2008). The value of investor protection: Firm evidence from crossborder mergers. Review of Financial Studies, 21(2), 605-648. https://doi.org/10.1093/rfs/hhm089.

Brouthers, K. D., \& Dikova, D. (2010). Acquisitions and real options: The Greenfield alternative. Journal of Management Studies, 47(6), 1048-1071. https://doi.org/10.1111/ j.1467-6486.2009.00875.x.

Calori, R., \& Lubatkin, M. (1994). Euro mergers 1993: Viewpoints and predictions. In von G. Krogh et al. (Eds.), The Management of Corporate Acquisitions (pp. 128-143). London: Palgrave Macmillan UK.

Campa, J. M., \& Hernando, I. (2004). Shareholder value creation in European M\&As. 
European financial management, 10(1), 47-81. https://doi.org/10.1111/j.1468-036X.2004.00240.x.

Chari, A., Chen, W., \& Dominguez, K. M. (2012). Foreign ownership and firm performance: Emerging market acquisitions in the United States. IMF Economic Review, 60(1), 1-42. https://doi.org/10.1057/imfer.2012.1.

Chari, A., Ouimet, P. P., \& Tesar, L. L. (2004a). Cross border mergers and acquisitions in emerging markets: The stock market valuation of corporate control [EFA 2004 Maastricht Meetings Paper No. 3479]. New York: SSRN.

Chari, A., Ouimet, P. P., \& Tesar, L. L. (2004b). Acquiring control in emerging markets: Evidence from the stock market [NBER Working Paper No. w10872]. New York City: NBER.

Chari, A., Ouimet, P. P., \& Tesar, L. L. (2010). The value of control in emerging markets. Review of Financial Studies, 23(4), 1741-1770. https://doi.org/10.1093/rfs/hhp090.

Chen, C., \& Su, R. (1997). Do crossborder acquisitions of US targets differ from US domestic takeover targets? Global Finance Journal, 8(1), 71-82. https://doi.org/10.1016/ S1044-0283(97)90006-5.

Collins, J. D., Holcomb, T. R., Certo, S. T., Hitt, M. A., \& Lester, R. H. (2009). Learning by doing: Cross-border mergers and acquisitions. Journal of Business Research, 62(12), 1329-1334. https://doi.org/10.1016/j. jbusres.2008.11.005.

Conklin, D. W. (2005). Cross-border mergers and acquisitions: $A$ response to environmental transformation. Journal of World Business, 40(1), 29-40. https://doi. org/10.1016/j.jwb.2004.10.003.

Conn, R. L., \& Connell, F. (1990). International mergers: returns to US and British firms. Journal of Business Finance \& Accounting, 17(5), 689-711. https://doi. org/10.1111/j.1468-5957.1990.tb00568.x.

Degbey, W. Y., \& Hassett, M. E. (2016). Creating Value in Cross-Border M\&As through Strategic Network. In H. Tüselmann et al. (Eds.), Impact of International Business (pp. 158-177). London: Palgrave Macmillan UK.

DePamphilis, D. M. (2015). Cross-Border Mergers and Acquisitions: Analysis and Valuation. In D. M. DePamphilis (Ed.), Mergers, Acquisitions, and Other Restructuring Activities (pp. 659-692). Amsterdam: Elsevier Science.

Erel, I., Liao, R., \& Weisbach, M. (2012). Determinants of cross-border mergers and acquisitions. Journal of Finance, 67(3),
1045-1082. https://doi.org/10.1111/j.1540-6261. 2012.01741.x.

Eurostat. (2016). Database. Retrieved October 25, 2016, from http://ec.europa.eu/ eurostat/data/database.

Fama, E. F., Fisher, L., Jensen, M. C., \& Roll, R. (1969). The Adjustment of Stock Prices to New Information. International Economic Review, 10(1), 1-21. https://doi. org/10.2307/2525569.

Gavurová, B., Vagašová, T., \& Kováč, V. (2016). Competitiveness Assessment of Slovak Republic Regions. In European Financial Systems 2016: Proceedings of the $13^{\text {th }}$ International Scientific Conference (pp. 175). Brno: Masaryk University.

Georgopoulos, A., Argyros, G., \& Boura, G. (2008). Which targets stimulate crossborder acquisitions? An empirical investigation of industrial organization and trade factors within a competition framework of international and domestic acquisition targets. Journal of Industry, Competition and Trade, 8(1), 55-72. https://doi.org/10.1007/s10842-007-0011-0.

Goergen, M., \& Renneboog, L. (2004). Shareholder Wealth Effects of European Domestic and Cross-border Takeover Bids. European Financial Management, 10(1), 9-45. https://doi. org/10.1111/j.1468-036X.2004.00239.x.

Graham, G., Martey, E., \& Yawson, A. (2008). Acquisitions from UK firms into emerging markets. Global Finance Journal, 19(1), 56-71. https://doi.org/10.1016/j.gfj.2007.11.001.

Gregoric, A., \& Vespro, C. (2009). Block trades and the benefits of control in Slovenia. Economics of Transition, 17(1), 175-210. https:// doi.org/10.1111/j.1468-0351.2009.00332.x.

Grigorieva, S., \& Petrunina, T. (2015). The performance of mergers and acquisitions in emerging capital markets: New angle. Journal of Management Control, 26(4). https://doi. org/10.1007/s00187-015-0219-9.

Guadalupe, M., Kuzmina, O., \& Thomas, C. (2012). Innovation and foreign ownership. The American Economic Review, 102(7), 35943627. https://doi.org/10.1257/aer.102.7.3594.

Gubbi, S. R., Aulakh, P. S., Ray, S., Sarkar, M. B., \& Chittoor, R. (2010). Do international acquisitions by emerging-economy firms create shareholder value? The case of Indian firms. Journal of International Business Studies, 41(3), 397-418. https://doi.org/10.1057/jibs.2009.47.

Hijzen, A., Görg, H., \& Manchin, M. (2008). Cross-border mergers and acquisitions and the 
role of trade costs. European Economic Review, 52(5), 849-866. https://doi.org/10.1016/j. euroecorev.2007.07.002.

Hitt, M. A., Harrison, J., Ireland, R. D., \& Best, A. (1998). Attributes of successful and unsuccessful acquisitions of U.S. firms. British Journal of Management, 9(2), 91-114. https://doi.org/10.1111/1467-8551.00077.

Hitt, M. A., Keats, B. W., \& DeMarie, S. M. (1998). Navigating in the new competitive landscape: Building strategic flexibility and competitive advantage in the 21st century. The Academy of Management Executive, 12(4), 22-42. https://doi.org/10.5465/ AME.1998.1333922.

Horn, H., \& Persson, L. (2001). The equilibrium ownership of an international oligopoly. Journal of International Economics, 53(2), 307-333. https://doi.org/10.1016/S0022-1996(00)00059-3.

Kiymaz, H. (2004). Cross-border acquisitions of US financial institutions: Impact of macroeconomic factors. Journal of Banking \& Finance, 28(6), 1413-1439. https://doi. org/10.1016/S0378-4266(03)00125-0.

Lanine, G., \& Vander Vennet, R. (2007). Microeconomic determinants of acquisitions of Eastern European banks by Western European banks. Economics of Transition, 15(2), 285-308. https://doi.org/10.1111/j.14680351.2007.00288.x.

Lebedev, S., Peng, M. W., Xie, E., \& Stevens, C. E. (2015). Mergers and acquisitions in and out of emerging economies. Journal of World Business, 50(4), 651-662. https://doi. org/10.1016/j.jwb.2014.09.003.

Lowinski, F., Schiereck, D., \& Thomas, T. W. (2004). The effect of cross-border acquisitions on shareholder wealth-evidence from Switzerland. Review of Quantitative Finance and Accounting, 22(4), 315-330. https://doi. org/10.1023/B:REQU.0000032601.84464.52.

Marković, D., Rakita, B., \& Filipović, D. (2016). Strategic Importance of Cross-Border Acquisitions for Emerging Market Multinationals. In I. Vrdoljak Raguž et al. (Eds.), Neostrategic Management (pp. 189-201). Cham: Springer International Publishing.

Markowitz, H. (1959). Portfolio selection: Efficient diversification of investments. Cowles Foundation monograph no. 16. New York: John Wiley \& Sons, Inc.

Meyer, K. E. (2003). Management challenges in privatization acquisitions in transition economies. Journal of World Business,
37(4), 266-276. https://doi.org/10.1016/S10909516(02)00093-7.

Meyer, M. L. (2011). Erfolgsfaktoren bei Mergers \& Acquisitions - Eine empirische Untersuchung externer Einflussfaktoren auf den Transaktionserfolg aus Käufersicht (Unpublished doctoral dissertation). Wuppertal: Bergische Universität Wuppertal.

Mitchell, M. L., \& Stafford, E. (2000). Managerial Decisions and Long-Term Stock Price Performance. The Journal of Business, 73(3), 287-329. https://doi.org/10.1086/209645.

Moeller, S. B., Schlingemann, F. P., \& Stulz, R. M. (2004). Firm size and the gains from acquisitions. Journal of Financial Economics, 73(2), 201-228. https://doi.org/10.1016/j.jfineco.2003.07.002.

Moschieri, C., \& Campa, J. M. (2014). New trends in mergers and acquisitions: Idiosyncrasies of the European market. Journal of Business Research, 67(7), 1478-1485. https://doi.org/10.1016/j.jbusres.2013.07.018.

Moschieri, C., Ragozzino, R., \& Campa, J. M. (2014). Does Regional Integration Change the Effects of Country-Level Institutional Barriers on M\&A? The Case of the European Union. Management International Review, 54(6), 853-877. https://doi.org/10.1007/s11575-014-0206-7.

Nadolska, A., \& Barkema, H. G. (2007). Learning to internationalise: The pace and success of foreign acquisitions. Journal of International Business Studies, 38(7), 1170-1186. https://doi.org/10.1057/palgrave.jibs.8400318.

Nagano, M., \& Yuan, Y. (2007). Crossborder acquisitions in a transition economy: recent experiences of China and India. Tokyo: Seikei University.

Neary, J. P. (2007). Cross-border mergers as instruments of comparative advantage. The Review of Economic Studies, 74(4), 1229-1257. https://doi.org/10.1111/j.1467-937X.2007.00466.x.

Norburn, D., \& Schonberg, R. (1994). European Cross-Border Acquisition: How Was It For You? Long Range Planning, 27(4), 25-34. https://doi.org/10.1016/0024-6301(94)90053-1.

Otchere, I., \& Ip, E. (2006). Intra-industry effects of completed and cancelled cross border acquisitions in Australia: A test of the acquisition. Pacific-Basin Finance Journal, 14(2), 209-230. https://doi.org/10.1016/ j.pacfin.2005.06.006.

Pablo, E. (2009). Determinants of crossborder M\&As in Latin America. Journal of Business Research, 62(9), 861-867. https://doi. org/10.1016/j.jbusres.2008.10.004. 
Peng, M. W. (2012). The global strategy of emerging multinationals from China. Global Strategy Journal, 2(2), 97-107. https://doi. org/10.1111/j.2042-5805.2012.01030.x.

Poghosyan, T., \& De Haan, J. (2010). Determinants of cross-border bank acquisitions in transition economies. Economics of Transition, 18(4), 671-696. https://doi. org/10.1111/j.1468-0351.2010.00393.x.

Pop, D. (2006). M\&A market in transition economies: Evidence from Romania. Emerging Markets Review, 7(3), 244-260. https://doi. org/10.1016/j.ememar.2006.01.003.

Rabbiosi, L., Elia, S., \& Bertoni, F. (2012). Acquisitions by EMNCs in developed markets: An organizational learning perspective. Management International Review, 52(2), 192-212. https://doi.org/10.1007/s11575-012-0134-3.

Rani, N., Yadav, S., \& Jain, P. K. (2016). Mergers and Acquisitions: An Introduction. In N. Rani et al. (Eds.), Mergers and Acquisitions, India Studies in Business and Economics. Singapore: Springer. https://doi. org/10.1007/978-981-10-2203-6_1.

Rao, N. V., \& Reddy, K. S. (2015). The impact of the global financial crisis on crossborder mergers and acquisitions: A continental and industry analysis. Eurasian Business Review, 5(2), 309-341. https://doi.org/10.1007/ s40821-015-0028-y.

Roberts, B. M., Thompson, S., \& Mikolajczyk, K. (2008). Privatization, foreign acquisition and the motives for FDI in Eastern Europe. Review of World Economics, 144(3), 408-427. https://doi.org/10.1007/s10290-008-0154-z.

Rossi, S., \& Volpin, P. F. (2004). Crosscountry determinants of mergers and acquisitions. Journal of Financial Economics, 74(2), 277-304. https://doi.org/10.1016/j. jfineco.2003.10.001.

Rugman, A. M., \& Verbake, A. (1991). Europe 1992 and competitive strategies for North American firms. Business Horizons, 11(6), 76-81. https://doi.org/10.1016/00076813(91)90114-B.

Sanders, W. G. (2001). Behavioral responses of CEOs to stock ownership and stock option pay. Academy of Management Journal, 44(3), 477-492. https://doi. org/10.2307/3069365.

Sharma, A., \& Raat, E. (2016). Acquiring control in emerging markets: Foreign acquisitions in Eastern Europe and the effect on shareholder wealth. Research in International
Business and Finance, 37, 153-169. https://doi. org/10.1016/j.ribaf.2015.09.032.

Shimizu, K., Hitt, M. A., Vaidyanath, D., \& Pisano, V. (2004). Theoretical foundations of cross-border mergers and acquisitions: A review of current research and recommendations for the future. Journal of International Management, 10(3), 307-353. https://doi.org/10.1016/j. intman.2004.05.005.

Soltes, V., \& Gavurova, B. (2014). Innovation policy as the main accelerator of increasing the competitiveness of small and medium-sized enterprises in Slovakia. Procedia Economics and Finance, 15, 1478-1485. https://doi. org/10.1016/S2212-5671(14)00614-5.

Spodniak, J., \& Cesnak, M. (2010). Fúzie a akvizície: Bežná súčast' rastovej stratégie spoločností po celom svete. Retrieved September 15, 2013, from http://www. investujeme.sk/fuzie-a-akvizicie-bezna-sucastrastovej-strategie-spolocnostipo-celom-svete/.

Statista. (2018). Mergers and acquisitions in Europe - Statistics \& Facts. Retrieved October 25, 2017, https://www-statista-com. ezproxy.hwr-berlin.de/topics/3339/mergersand-acquisitions-in-europe/.

Trojanowski, G. (2008). Equity block transfers in transition economies: Evidence from Poland. Economic Systems, 32(3), 217-238. https://doi.org/10.1016/j.ecosys.2007.11.002.

Uhlenbruck, K., \& De Castro, J. O. (2000). Foreign acquisitions in Central and Eastern Europe: Outcomes of privatization in transitional economies. Academy of Management Journal, 43(3), 381-402. https://doi.org/10.5465/1556401.

UNCTAD. (2000). World Investment Report 2000: Cross-border Mergers and Acquisitions and Development, United Nations. Retrieved November 14, 2016, from http://unctad.org/en/ Docs/wir2000_en.pdf.

UNCTAD. (2016). World Investment Report 2016: Investor Nationality: Policy Challenges. Retrieved November 14, 2016, from http://unctad. org/en/PublicationsLibrary/wir2016_en.pdf.

Vasconcellos, G. M., \& Kish, R. J. (1998). Cross-border mergers and acquisitions: The European-US experience. Journal of Multinational Financial Management, 8(4), 431-450. https://doi. org/10.1016/S1042-444X(98)00041-3.

Weston, J. F., Chung, K. S., \& Hoang, S. E. (1998). Mergers, restructuring and corporate control. New Delhi: Prentice-Hall. 


\section{Finance}

Wulff, Ch. (2001). Kapitalmarktreaktionen auf Nennwertumstellungen. Berlin: SpringerVerlag $\mathrm{GmbH}$.

Young, M. N., Tsai, T., Wang, X., Liu, S., \& Ahlstrom, D. (2014). Strategy in emerging economies and the theory of the firm. Asia Pacific Journal of Management, 31(2), 331-354. https://doi.org/10.1007/s10490-014-9373-0.

Zhu, P. (2011). Persistent performance and interaction effects in sequential crossborder mergers and acquisitions. Journal of Multinational Financial Management, 21(1), 1839. https://doi.org/10.1016/j.mulfin.2010.12.004.

Zhu, P., Jog, V., \& Otchere, I. (2014). Idiosyncratic volatility and mergers and acquisitions in emerging markets. Emerging Markets Review, 19, 18-48. https://doi. org/10.1016/j.ememar.2014.04.001.
Ing. Tim Langenstein Technical University of Kosice Faculty of Economics Slovakia tim.langenstein@ebootis.de

Ing. Anna Vojtková, PhD. Berlin Institute of Finance, Innovation and Digitalization Germany anna.vojtkova@bifid.sk

Prof. Dr. Martin Užík Berlin School of Economics and Law Berlin Institute of Finance, Innovation and Digitalization Germany martin.uzik@hwr-berlin.de

Andreas Ruepp LLM Berlin Institute of Finance, Innovation and Digitalization Germany andreas.ruepp@bifid.org 


\title{
CROSS-BORDER ACQUISITIONS IN CENTRAL AND EASTERN EUROPE WITH FOCUS ON RUSSIA VERSUS GERMANY DEALS: AN EMPIRICAL ANALYSIS
}

\author{
Tim Langenstein, Anna Vojtková, Martin Užík, Andreas Ruepp
}

Globalization, deregulation and the attendant liberalization of capital markets have made cross border mergers and acquisitions attractive to firms seeking to strategically position themselves within the global economy to take advantage of the opportunities that globalization offers. As a result, cross-border acquisition and merging activities have increased dramatically over the recent decades. Because of the fall of the "iron curtain" and the proceeds of European integration, mainly the European single market has created new possibilities. Moreover, one of the main results of globalization is a greater role of emerging markets in the global economy, especially in the area of foreign direct investment. The paper therefore analyses announced and completed cross border acquisitions between a public listed acquirer and target companies from Central and Eastern Europe and associated reactions of the capital markets. The analysis focuses, in particular, on cross-border Russia versus Germany deals. Examining the sample of 11,085 announced deals over the period from January 1990 through December 2014, the analysis points out some important trends in the global economy in the area of companies acquisition and merging activities. In summary, it can be emphasized that Central and Eastern Europe as the region is very attractive from the market's perspective due to the expected growth rates and the framework conditions as well as from the perspective of Western European investors. Analysis results indicate that Russian market is better in the area of cross-border acquisitions than remaining Central and Eastern European markets. It allows us to suggest that it is worthier investing in Russia than in remaining Central and Eastern Europe.

Key Words: Cross border acquisitions, abnormal return, Central and Eastern Europe.

JEL Classification: C39, C49, F65, P45.

DOI: 10.15240/tul/001/2018-4-014 